\title{
Perceived economic self-sufficiency: a country- and generation-comparative approach
}

\section{Jale Tosun ${ }^{1} \cdot$ José L. Arco-Tirado $^{2}$ - Maurizio Caserta ${ }^{3} \cdot$ Zeynep Cemalcilar $^{4}$.} Markus Freitag ${ }^{5}$ Felix Hörisch ${ }^{1}$ - Carsten Jensen ${ }^{6}$ - Bernhard Kittel ${ }^{7}$. Levente Littvay $^{8}$ - Martin Lukeš ${ }^{9}$ William A. Maloney ${ }^{10}$ - Monika Mühlböck ${ }^{7}$. Emily Rainsford $^{10}$ - Carolin Rapp ${ }^{11}$ - Bettina Schuck ${ }^{12} \cdot$ Jennifer Shore $^{13}$. Nadia Steiber $^{14} \cdot$ Nebi Sümer $^{15} \cdot$ Panos Tsakloglou $^{16} \cdot$ Mihaela Vancea $^{17}$. Federico Vegetti ${ }^{18}$

Abstract Existing datasets provided by statistical agencies (e.g. Eurostat) show that the economic and financial crisis that unfolded in 2008 significantly impacted the lives and livelihoods of young people across Europe. Taking these official statistics as a starting point, the collaborative research project "Cultural Pathways to

Electronic supplementary material The online version of this article (https://doi.org/10.1057/ s41304-018-0186-3) contains supplementary material, which is available to authorized users.

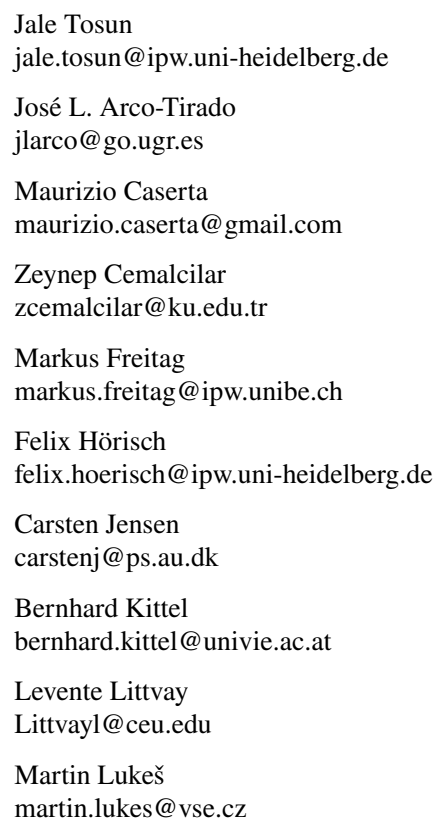


Economic Self-Sufficiency and Entrepreneurship in Europe" (CUPESSE) generated new survey data on the economic and social situation of young Europeans (1835 years). The CUPESSE dataset allows for country-comparative assessments of young people's perceptions about their socio-economic situation. Furthermore, the dataset includes a variety of indicators examining the socio-economic situation of both young adults and their parents. In this data article, we introduce the CUPESSE dataset to political and social scientists in an attempt to spark a debate on the measurements, patterns and mechanisms of intergenerational transmission of economic self-sufficiency as well as its political implications.

Keywords Economic self-sufficiency $\cdot$ Europe $\cdot$ Parents $\cdot$ Transmission · Youth · Survey data

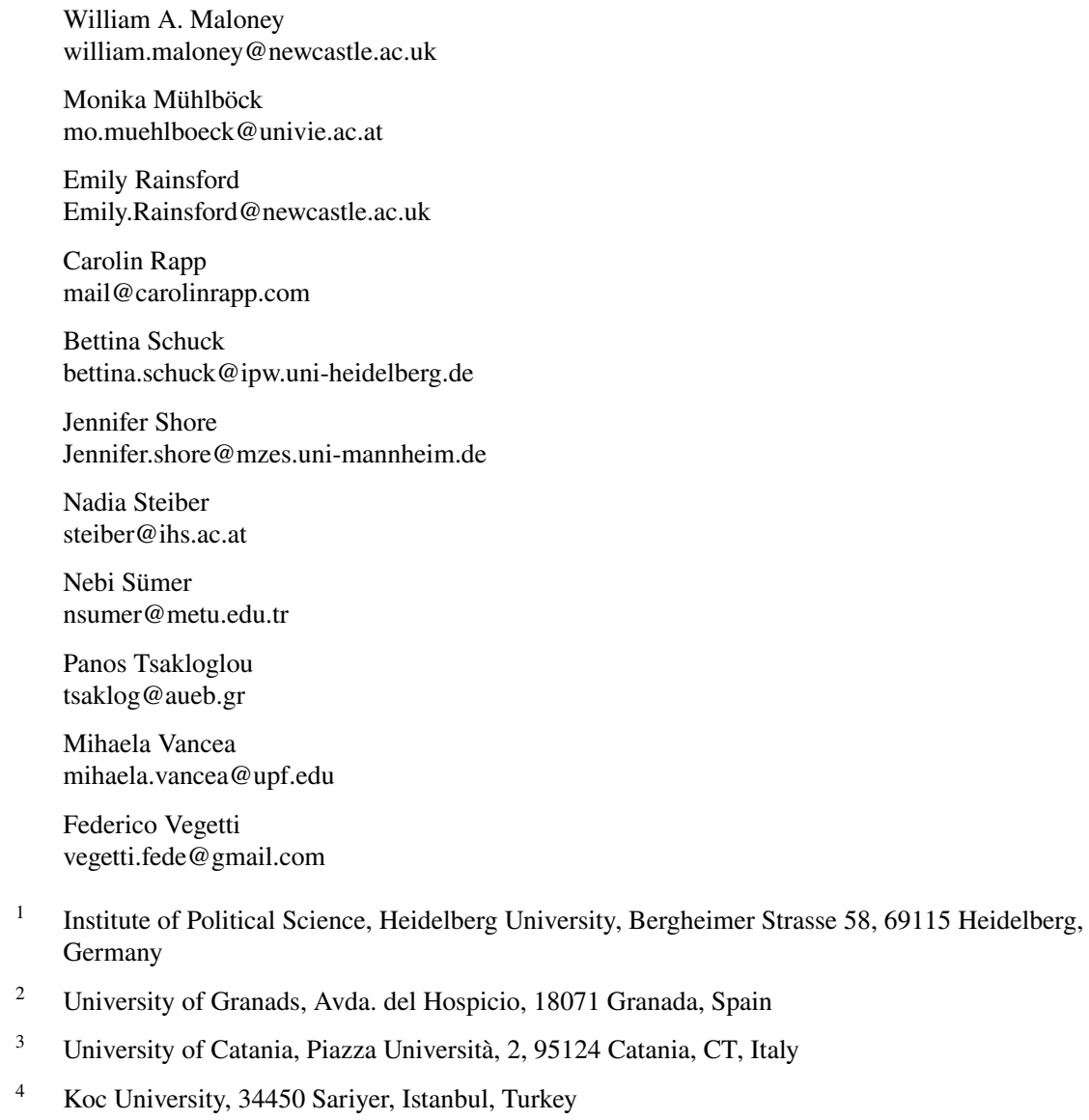




\section{Introduction}

The concept of economic self-sufficiency features prominently in many international organisations' publications (e.g. Hetling et al. 2016). The Organisation for Economic Cooperation and Development (OECD), for example, provides an aggregatelevel definition of self-sufficiency, which concentrates on the "extent of participation in the economy and society and how well individuals are able to get through daily life on their own" (OECD 2007: 21). In terms of measurement, the OECD refers to the overall employment rate, the share of the population in jobless households, the average number of years of schooling and the average school performance of children at age 15. In addition to this general concept of economic self-sufficiency, there exist more specific definitions reflecting the characteristics of particular target groups (Gowdy and Pearlmutter 1993). Despite the prominence it gained, the concept of economic self-sufficiency has also been criticised for being difficult to define and even more difficult to evaluate (Leibson 2005).

Although conceptualising and measuring economic self-sufficiency is challenging, it warrants closer attention due to its immediate implications for an important topic in political science: attitudes towards welfare state and redistribution (Alesina and Giuliano 2011; Svallfors 2012). Citizens' preferences for redistributive policies can be traced back to both economic self-interest and personal beliefs (Alesina and Giuliano 2011; Dion and Birchfield 2010; Jost 2006). Furthermore, individuals draw inferences about the degree of inequality and poverty in society from their immediate social context, such as family and friends. These inferences, in turn, can shape attitudes towards welfare provision and redistribution (Dawtry et al. 2015). Learning

5 Institute of Political Science, University of Bern, Fabrikstrasse 8, 3012 Bern, Switzerland

6 Aarhus University, Bartholins Allé 7, 8000 Aarhus C, Denmark

7 University of Vienna, Oskar-Morgenstern-Platz 1, 1090 Vienna, Austria

8 Central European University, Nador u. 9, Budapest 1051, Hungary

9 Department of Entrepreneurship, University of Economics, Prague, W. Churchill Sq. 4, 13067 Prague 3, Czech Republic

10 Newcastle University, Newcastle upon Tyne NE1 7RU, UK

11 University of Copenhagen, Øster Farimagsgade 5, 1353 Copenhagen, Denmark

12 Institute of Political Science, Heidelberg University, Bergheimerstr. 20, Heidelberg, Germany

13 Mannheim Centre for European Social Research, University of Mannheim, MZES, 68131 Mannheim, Germany

14 Institute for Advanced Studies, Josefstädter Str. 39, 1080 Vienna, Austria

15 Middle East Technical University, B236 Social Sciences Building, 06800 Ankara, Turkey

16 International and European Economic Studies, Athens University of Economics and Business, 76 Patission Str., 10434 Athens, Greece

17 Pompeu Fabra University, Plaça de la Mercè, 10, 08002 Barcelona, Spain

18 Department of Social and Political Sciences, University of Milan, Via Conservatorio 7, 20122 Milan, Italy 
more about young people's perceptions of their own economic self-sufficiency is therefore crucial for understanding the social and attitudinal bases of their preferences in such a central policy domain.

The collaborative research project "Cultural Pathways to Economic Self-Sufficiency and Entrepreneurship in Europe" (CUPESSE) funded by the European Commission from February 2014 to January 2018 focused on young adults, their economic situation and their values and attitudes regarding work and education (Tosun et al. 2018). ${ }^{1}$ While an extremely heterogeneous group with a variety of different needs, young people face considerable challenges and risks in terms of transitioning from school to work, entering the labour market and, ultimately, attaining some form of economic self-sufficiency. Many of the risks and hurdles young people must navigate along their journey to adulthood were simply not present, or at least not to the same degree, when their parents and grandparents were their age (O'Reilly et al. 2015).

Traditionally, in the European Union (EU), youth unemployment has mostly been a more acute issue in the Southern European countries, but the 2008 financial crisis and the subsequent sovereign debt crises have exacerbated the situation across Europe (see Lahusen et al. 2013; O'Reilly et al. 2015; Tosun et al. 2014, 2016, 2017; Tosun 2017). Spells of unemployment early in life are likely to leave scars, which can also affect later employment prospects (Dvouletý et al. 2018). Unemployment may also have an impact on political socialisation and patterns of political behaviour (Albacete 2014; Emmenegger et al. 2017; Neundorf et al. 2013).

Many young Europeans hold precarious jobs and must therefore rely on the economic support of their parents. Baranowska-Rataj et al. (2016) highlight this in the UK, where employment became increasingly precarious between the 1990s and the start of the 2000s, particularly for (young) men with low educational qualifications. This type of employment (e.g. through zero-hour contracts or fixed-term contracts) reduces young people's economic autonomy and increases their financial vulnerability. Moreover, precarious working conditions can also affect political attitudes with regard to welfare and redistributive preferences.

In this article, we present the CUPESSE dataset and discuss its relevance for political economy and political sociology. We first introduce the measurement approach developed by the consortium to assess young people's perceptions of their economic self-sufficiency. Second, we contrast young people's economic situations with their parents in order to gain initial insights into whether intergenerational differences exist. Third, we compare young people's attitudes with their parents' attitudes about two interrelated social policy domains: welfare benefits and universal basic income. Lastly, we look at the correlates of young respondents' attitudes using multiple regression analysis and offer some concluding remarks.

\footnotetext{
1 The CUPESSE dataset including the full documentation of the data can be obtained from the GESIS data archive: https://search.gesis.org/research_data/ZA7475. The dataset for replicating the analysis presented in this paper can be accessed from the European Political Science homepage.
} 


\section{Conceptual considerations for surveying two generations}

Two strands of research motivate our interest in comparing the attitudes of young people with those of their parents. First, the literature in political science has provided extensive insights into generational differences with regard to attitudes towards political institutions and policies as well as political participation (e.g. Melo and Stockemer 2014; Abendschön and Tausendpfund 2017). A recent example is the voting behaviour in the Brexit referendum in the UK: young people mostly supported the country's membership in the EU, whereas older citizens predominantly voted in favour of leaving (Hobolt 2016).

Second, and drawing on advances in social psychology, intergenerational cultural transmission refers to the transmission of values, beliefs, knowledge, practices from one generation to the next. In this process, parents generally have the most substantial transmissive role (Abendschön 2013; Schönpflug 2009; Trommsdorff 2009; Van Deth et al. 2011). While there are of course other factors that can influence socialisation, such as peers and other social groups (Quintelier 2013), in line with the extant literature, we emphasise the crucial role of the family for early socialisation, fundamental value orientations and first experiences that shape both lifestyles and life courses (e.g. Albacete 2014; Neundorf et al. 2013; Abendschön and Tausendpfund 2017).

Intergenerational transmission can also involve different forms of capital as defined by Bourdieu (1997). Economic capital is immediately and directly convertible into monetary resources and is particularly suited to institutionalisation in the form of property rights. Some simple examples for economic capital are money, wealth and all sorts of income. Access to economic capital increases the probability that young people receive financial support for their education (Campanella et al. 2013).

Social capital represents the total of actual and potential resources that are associated with the possession of a permanent network of more or less institutionalised relationships based on mutual acquaintance or recognition (Bourdieu 1997; see also Maloney and Roßteutscher 2009; Roßteutscher 2010). Examples of social capital are social relations such as friendships, trust relationships, business relationships or memberships in groups, organisations or professional associations (see Maloney and van Deth 2010; Christoforou 2011; Freitag and Kirchner 2011; Cemalcilar and Gökşen 2014). Social networks play a crucial role in the path to economic self-sufficiency (Lorenzini and Giugni 2012), as they influence the individual's perception of opportunities and thereby conditions, for example, an individual's decision to pursue self-employment (Davidsson and Honig 2003; Jagannathan et al. 2017; Rapp et al. 2018). The family's social capital is likely to influence a child's social capital, for s/he can also rely on the parents or relatives, friends and acquaintances when developing their own network of social relations.

The dominant interpretation of cultural capital focuses on competences within the elite culture and has become distinct from aspects such as educational skills and achievements. When conceived in this way, empirical research has shown that cultural capital is transmitted from parents to their children (e.g. Kraaykamp and Nieuwbeerta 2000; Kraaykamp and Van Eijck 2010). 
We go one step further and argue that the parent's socio-economic status defines the reference point for young people's career expectations. Career and educationrelated aspirations of parents are likely to influence the career choices their children make. ${ }^{2}$ Furthermore, parents can serve as role models and increase the perceived feasibility of certain career decisions. For example, having parents who are selfemployed can make this career path appear more feasible (Jagannathan et al. 2017; Mühlböck et al. 2017; Vegetti and Adăscăliţei 2017).

There are good reasons to study young people's attitudes and compare them to their parents (see also studies on genetic transmission such as Alford et al. 2005; Fazekas and Littvay 2015). Families are arguably the most important socialising force when it comes to young people's economic and career outcomes. Such outcomes are not only closely linked to economic self-sufficiency, but also affect political attitudes and political participation (Albacete 2014; Neundorf et al. 2013).

\section{Details on the CUPESSE dataset}

The main goal of the CUPESSE project was to collect data on different indicators related to the concept of economic self-sufficiency and to explore the role families play in the journey from education to employment. CUPESSE involved social scientists at academic institutions in 11 countries: Austria, the Czech Republic, Denmark, Germany, Greece, Hungary, Italy, Spain, Switzerland, Turkey and the UK. The country selection reflects important dimensions of economic variation within Europe (e.g. Tosun et al. 2016) as well as variation with regard to their political systems and welfare state arrangements (e.g. Jensen 2008; Bonoli and Natali 2012; Chevalier 2016; Jensen et al. 2018; Tosun et al. 2017). CUPESSE involved researchers from all across the social sciences: sociology, political science, psychology, economics, education and business administration.

The core activity of the CUPESSE project was the development of a survey instrument designed to study young adults' attitudes regarding work and education as well as their current socio-economic situation. Although many statistical agencies use age 25 as the end of youth, we took seriously the empirical evidence documenting the prolonged transition to adulthood in many societies (e.g. Arnett 2014). Our sample therefore included young adults between the ages of 18 (to ensure we were only working with legal adults) and 35. Moreover, we were interested in how social, cultural and economic capital (e.g. Bourdieu 1997) not only affects young people's current situation, but also whether these forms of capital were transmitted from their parents (see, e.g. Kraaykamp and Nieuwbeerta 2000; Kraaykamp and Van Eijck 2010). The development and implementation of the CUPESSE survey involved both

\footnotetext{
${ }^{2}$ We are aware that attitudes on education and training are also affected by context variables such as the design of the political economy (see, e.g. Busemeyer and Jensen 2012).
} 
young Europeans and their parents, with separate questionnaires developed for each group. ${ }^{3}$

We asked the young survey respondents whom they considered to be their mother or father figure in order to identify the parents and also how to contact them. ${ }^{4}$ The response options went beyond biological parents and included the spouse/partner of a given parent, grandparents and other persons (which then had to be specified). Depending on how the young respondents answered the initial questions about whom they considered to be their parents, they were asked, for example, to provide information about their mother's and/or father's highest level of education and employment status. Consequently, we were able to gather a lot of parent-related information from the young people themselves. For other questions, we surveyed the parents directly. To this end, we first asked the young people whether it would be possible to contact their parents, ${ }^{5}$ whom we should best contact, ${ }^{6}$ and finally for the contact information of one or both parents.

The master version of the two questionnaires was written in English and represents the collaborative and iterative efforts of the entire project consortium. The English questionnaire was youth-proofed (discussed in depth with 12 young people as well as with youth workers providing employment support) by the project partners in Newcastle. ${ }^{7}$ In a next step, the master versions were translated into the respective national languages by each country team. To ensure that the different language versions of the English instrument were conceptually equivalent in each of the target countries, the questionnaires were subsequently translated back to English and then checked by bilingual language experts. The process of producing national questionnaires went well beyond simply translating them into their target languages- the response categories also had to be adapted for the respective countries. For example, the questionnaires for Austria, Germany and Switzerland ${ }^{8}$ are all in German, but the formulation of both the questions and the responses (e.g. for questions about education) varies across these three countries.

Nine of the 11 youth questionnaires were conducted online, one was conducted face-to-face using Computer Assisted Personal Interviewing (Hungary), and one was conducted face-to-face using paper and pencil (Turkey). The Hungarian and the Turkish teams could not rely on online surveying due to low Internet coverage. For

\footnotetext{
${ }^{3}$ Questionnaire pre-tests were conducted in each country between December 2015 and February 2016. Insights from the pre-tests were discussed during a project meeting in February 2016. The pre-testing mainly focused on ways to maximise the number of parental contacts provided by the young adult respondents.

4 The corresponding variables in the dataset are YQ28_mother and YQ28_father. In the UK, the polling firm randomly selected which parent to contact, which is one of the reasons why there are more fathers in the sample.

5 The variable in the dataset is YQCONTACT.

6 Captured by the variables PMCORD and PFCORD.

7 To see whether the questionnaire also adequately captured the demand side of youth labour, the teams at Heidelberg University and University of Vienna also carried out interviews with employers (Steiber 2016; Weiß and Schuck 2016).

8 The questionnaire for Switzerland was translated into German, French and Italian in accordance with similar surveys such as the European Social Survey.
}

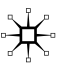


the parental surveys, most of the interviews were conducted using mixed modes, including online (Czech Republic, Denmark, Germany, Italy, UK), Computer Assisted Telephone Interviewing (Austria, Czech Republic, Germany, Hungary, Italy, Spain), Computer Assisted Personal Interviewing (Hungary) and paper and pencil (Switzerland, Turkey). This heterogeneity in parent survey modes was the result of the type of information young people provided us with when asked about how to contact their parent(s). For example, while some provided a telephone number, others gave only an email address. The various polling firms also provided guidance about how to best approach the parental generation (for details on Germany, see Shore and Tosun 2018). ${ }^{9}$

Despite the different survey modes, the sampling frames were consistent. For the youth questionnaire, survey companies were asked to provide a probability sample of individuals between the ages of 18 and 35 representative of employment status (e.g. employed; self-employed; unemployed; in education/training), NUTS 2 region, ${ }^{10}$ age group, education and migration background/minority group membership. For the parental questionnaire, the strategy consisted of recruiting all parents for which the youth provided contact information.

In terms of sample size, the minimum requirement per country was 1000 young adult respondents and 500 parents, with a reasonable proportion of fathers and mothers. It was important to agree to these minimum numbers since the practical constraints (e.g. the total number of individuals registered with the online panels) and the costs varied considerably across the individual countries.

Table 1 provides an overview of the number of completed questionnaires by young people (by gender) and their parents (broken down by whether the survey was completed by the mother, father or both). The table also shows the survey modes used for both groups of respondents in the individual countries. The CUPESSE dataset consists of 20,008 observations (5945 of which have data for at least one parent). What we are unable to show in the table is the vast number of variables included in the dataset, namely 429 variables (239 of which are from the youth questionnaire). ${ }^{11}$

\section{Economic self-sufficiency}

One of the goals of the CUPESSE project was to capture different aspects of economic self-sufficiency by building on a broad definition of the concept as "a situation in which a person is economically independent in the sense of not relying on

\footnotetext{
9 The polling firms contracted in the individual countries were: Gallup (Austria), Median (Czech Republic), TNS Gallup (Denmark), YouGov (Germany), MRB Hellas (Greece), TÁRKI (Hungary), SWG (Italy), Netquest (Spain), Gfs Bern (Switzerland), Infakto (Turkey) and IPSOS Mori (UK).

${ }^{10}$ NUTS stands for Nomenclature of Territorial Units for Statistics. It is a three-level geocode standard for referencing the administrative divisions of countries for statistical purposes developed by the EU. Here we refer to the second level of the referencing system-NUTS 2; these are the basic regions for the application of regional policies in the EU.

11 The complete CUPESSE dataset with additional information can be accessed via the GESIS data archive (see footnote 1).
} 


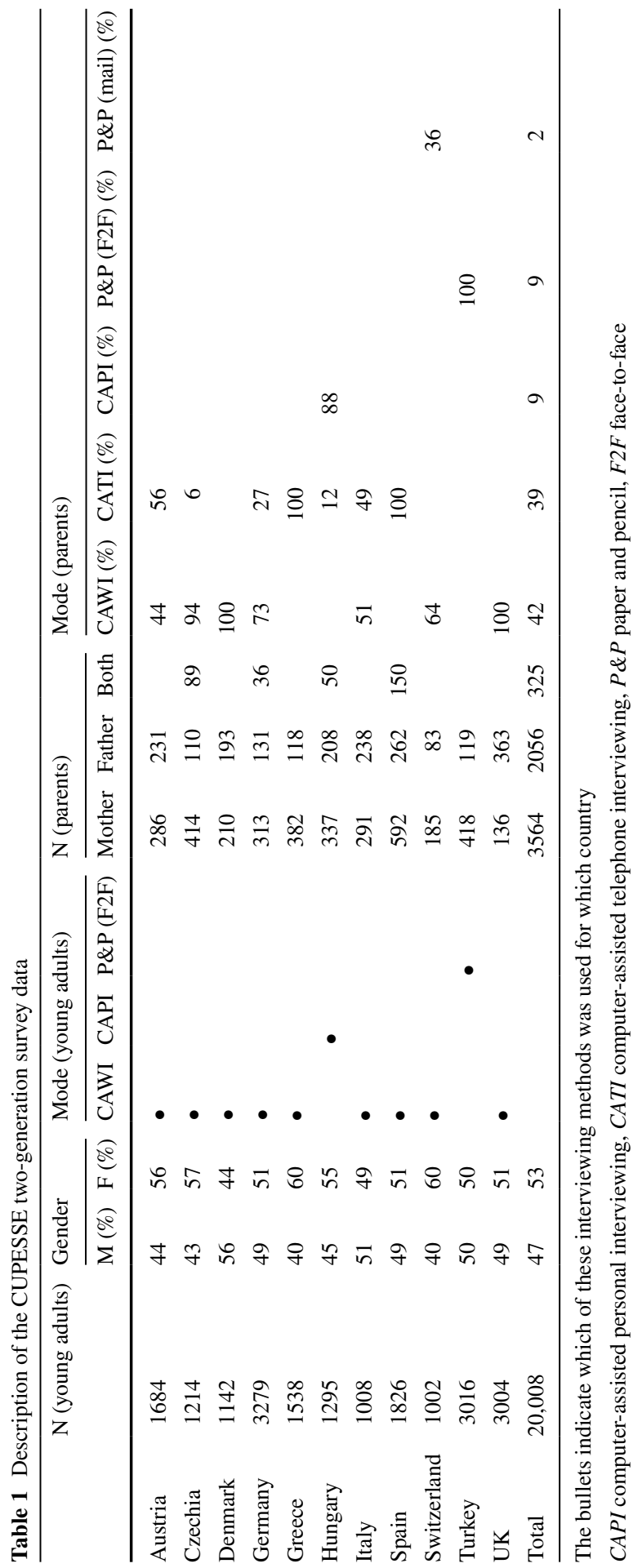


financial support from her family or the welfare system" (Warmuth et al. 2015: 5). In this view, participation in the labour market is but one of many elements to be considered, reasonably the first one of a chain which includes possible sources of external support. ${ }^{12}$ Additionally, to take full advantage of the individual-level focus of the project, the data also looked at respondents' perceptions of their own selfsufficiency. Such perceptions are the crucial link between the actual economic situation and individuals' attitudes. For instance, research in political behaviour has repeatedly shown that people's perceptions of the economy act as a filter between the objective economic conditions and electoral choices (e.g. Debus et al. 2014). Hence, by looking at respondents' assessments of their own economic self-sufficiency, the CUPESSE data offer a valuable resource to study the individual underpinnings of attitudes that are generally not captured by other indicators of economic performance.

One facet of economic self-sufficiency is income independence, that is, whether and to what extent respondents provide for themselves through paid jobs or selfemployment - versus relying on their family or on the state. This indicator is measured with an item battery, where respondents are asked to select all the sources of their income. ${ }^{13}$ From these observations, we can classify respondents based on whether their income fully or partially depends on the family or the state, or whether it is completely independent. However, having a fully independent income does not always imply being able to afford a decent standard of living, let alone being satisfied with one's own economic situation.

A second aspect of self-sufficiency is the housing situation of the young respondents, that is, whether they live with their parents (or other older family members). While this indicator might be heavily affected by people's own economic conditions in contexts (social and cultural) where the constraints to moving out of the parental home are primarily economic (see Isengard et al. 2017). The housing situation could also be due to other considerations (e.g. potential social stigma associated with living alone without being married). Moreover, when looking at young adults living with their parents, it is important to distinguish between those who never moved out of the parental home and those who moved back after living on their own for a certain period (the so-called boomerangers). ${ }^{14}$

Moving from objective indicators towards perceptions, we look at respondents' self-assessed economic conditions. Economically self-sufficient individuals are able to provide for themselves and afford a reasonable standard of living. This dimension

\footnotetext{
12 See Section A1 in the Supplemental Material for the frequencies of occupational status among the young respondents in the CUPESSE survey.

13 Options are paid and self-employment work, redundancy pay, unemployment or other social benefits, support from family members or by the partner, investments, savings, inherited money and other nonsocial benefits. The relevant variables are YQ10_a-YQ10_i.

14 The item battery YQ28a_0-YQ28a_8 captures whether respondents live alone or with other people, including parents, grandparents and other relatives, as well as their partner and/or children. Moreover, the question YQ28d captures whether the respondents have ever lived apart from their parents, which allowed us to distinguish the boomerangers from those who have never moved out from the parental home.
} 

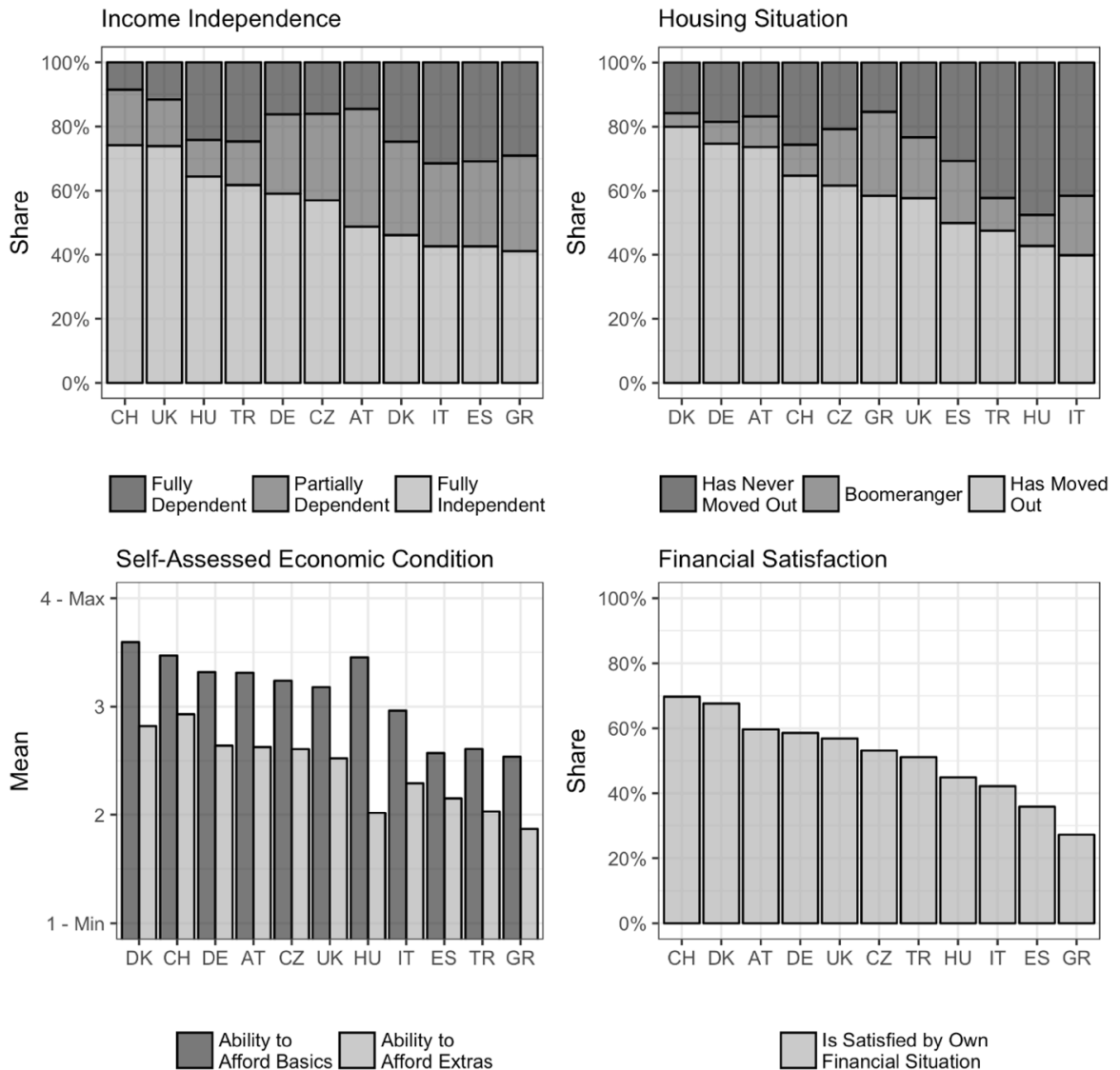

Is Satisfied by Own Financial Situation

Fig. 1 Indicators of economic self-sufficiency by country

has been captured in the CUPESSE questionnaire by asking respondents to what extent during the six months prior to the interview they were able to (1) pay their bills by themselves, (2) afford decent housing, (3) afford extras like trips or hobbies and (4) put some money aside. These four indicators capture two important aspects of economic self-sufficiency: the respondents' ability to afford basic living standards (items one and two) and to afford extras (items three and four). ${ }^{15}$

Finally, a subjective indicator, financial satisfaction, can provide further insights into the respondents' condition. Since this construct is an evaluation, it is of course sensitive to a number of unobservable benchmarks, for instance what respondents would consider to be a satisfactory situation for themselves, or how generally positive or negative their outlook on life is. However, when compared to more objective criteria discussed here, it provides an interesting insight into how young people's

\footnotetext{
15 The relevant variables are YQ9_a-YQ9_d. A similar distinction is also made by Gowdy and Pearlmutter (1993).
} 
expectations are met in their current conditions. In the CUPESSE data, this is measured by asking the respondents to rate the degree of satisfaction with their own financial situation on an ordinal four-point Likert scale. ${ }^{16}$

Figure 1 shows the country frequencies for all indicator types. ${ }^{17}$ In each panel, countries are sorted on the horizontal axis from high to low self-sufficiency with respect to the specific factor plotted. The figure illustrates how the indicators capture different aspects of self-sufficiency that do not necessarily appear alongside one another. For instance, looking at the two most objective facets on the top row, we see that Hungarian respondents are among the top three in our sample with respect to income independence, but they are among the bottom three when it comes to living independently from family. A similar albeit less extreme example of this pattern is Turkey. The opposite case is Denmark, where less than $50 \%$ of the respondents have a fully independent income, but about $80 \%$ of them live apart from their family - which is most likely due to the high proportion of students in the Danish sample. Looking at the two more subjective indicators on the bottom row, the pattern is rather consistent. For both indicators, the top four countries where respondents perceive themselves as better off are Denmark, Switzerland, Austria and Germany, while the Southern European countries all towards the bottom of the scale. Hungary is a somewhat interesting case, where respondents see themselves as very much able to afford basics but not extras. This is probably due to the very low costs of living in Hungary relative to the other countries in the sample (see Eurostat 2017).

But how do the young respondents fare in terms of economic self-sufficiency compared to their parents? The CUPESSE data allow the comparison of two generations of respondents by asking the same questions of economic self-sufficiency to both the young adults and their parents. We focus here on the subjective indicators of self-sufficiency, namely the stated ability to afford basics and extras and the satisfaction with one's own financial situation. While the two objective indicators discussed here are important, they use the contribution from the family (in terms of income or housing resources) as a baseline to determine the individual self-sufficiency of the young adults. The subjective indicators, on the other hand, can be measured in the same way for both parents and children; hence, they allow for a more straightforward comparison.

Figure 2 shows the difference between parents and children with respect to their self-assessed economic situation-that is, the extent to which the parents and children are able to afford basics and extras and their assessment of their financial satisfaction. The dotted lines cutting through the planes horizontally and vertically represent the medians with respect to the different indicators among the countries in the sample. The grey diagonal lines represent the perfect congruence between children's and parents' values. Unsurprisingly, most values are within the lower triangle, i.e. parents on average tend to evaluate their economic situation better and are more satisfied with their economic situation than their children. However, there are two

\footnotetext{
16 The relevant variable is YQ8.

17 For all figures, frequencies have been adjusted using post-stratification weights based on gender, age, education and NUTS 2 region.
} 

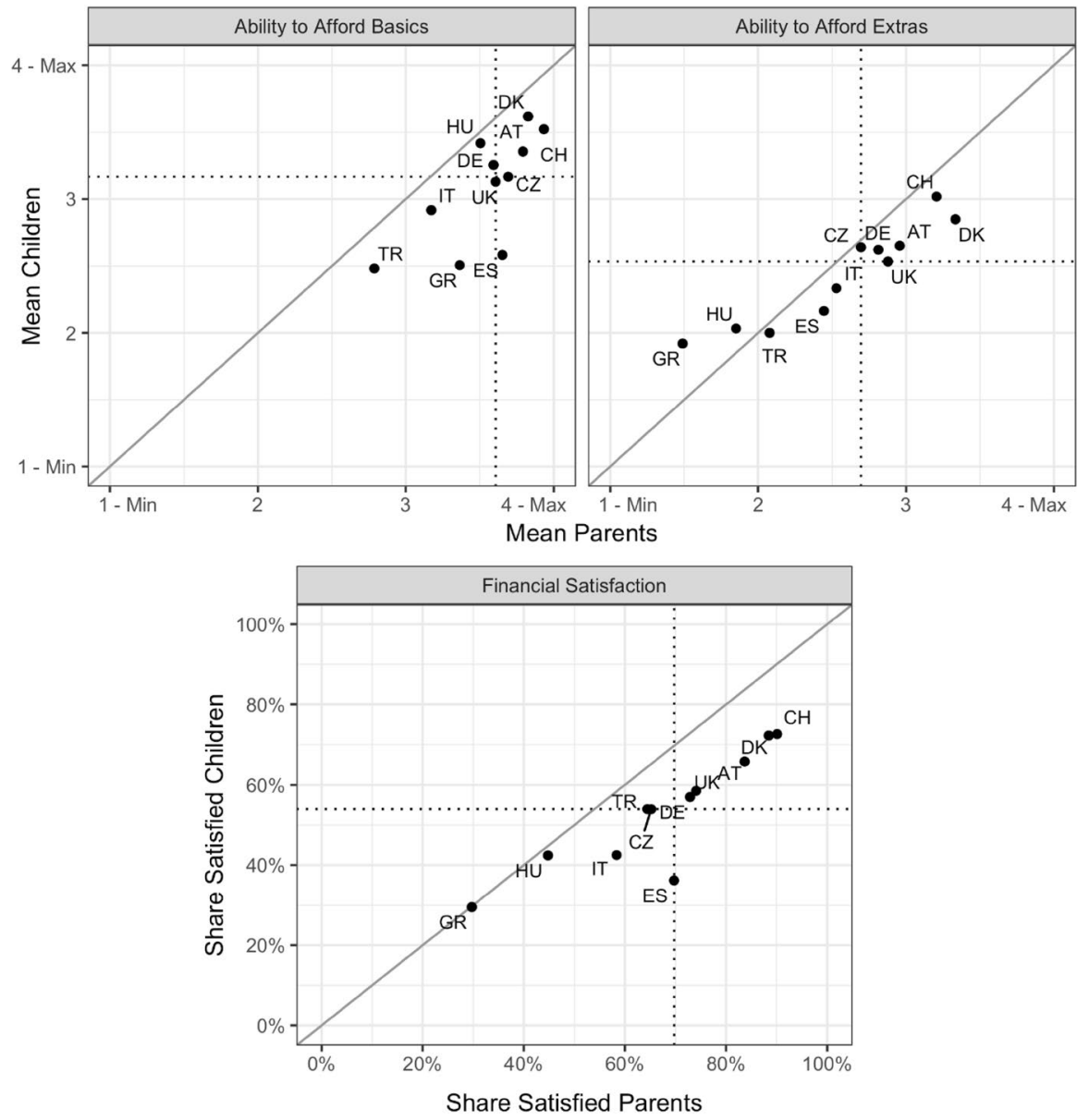

Fig. 2 Economic self-sufficiency and financial satisfaction of young people and their parents

instances where this is not the case: in Hungary and Greece, the young respondents judge their own ability to afford extras (i.e. to afford extra trips and hobbies and to put aside money) as higher than their parents. This might reflect a cultural shift between the two generations in these countries, wherein young people are perhaps more willing to treat themselves to extras than their parents. In fact, by comparing the distance from the diagonal lines of the points in the two top panels, this phenomenon appears to spread beyond Hungary and Greece: in general, the advantage of the parents over their children is more pronounced with respect to their ability to afford basics than to afford extras in all countries except Denmark. One last observation worth noting is the dramatic difference in parents' and their children's ability to afford basics in Spain and to a lesser extent in Greece. In the former case, parents rate their ability one point higher on average than their children, which on a fourpoint scale means a quarter of the full range. The Greek case is more puzzling, as 
the young respondents appear to be much less able to afford basic standard of living costs than their parents, but more able to afford extras. This is an interesting aspect of the data and deserves a more thorough investigation, especially considering the Greek experience with austerity (see Ladi 2014; Andriopoulou et al. 2018).

Moving on to financial satisfaction, the bottom panel tells a similar story. The absence of values in the upper triangle indicates that in no case are children on average more satisfied than their parents. However, the picture shows some interesting variation. For example, parents in Spain are almost twice as likely to be satisfied than their children (60\% vs. $36 \%$ ), whereas in Greece parents are nearly as dissatisfied as their children with their own finances (30\% in both cases). Looking at the countries' relative positions with respect to the median, it is clear that most crosscountry variation in terms of generational change occurs among the least affluent countries in the sample. All Southern and Central-Eastern European countries are within the bottom $50 \%$ of the distribution in terms of average financial satisfaction. While in Greece and Hungary there seems to be more intergenerational similarity, in Italy and Spain the older respondents are much more likely to be satisfied than the younger ones. The remaining and wealthier countries are sorted diagonally in nearperfect manner, indicating a striking similarity between the most affluent societies with respect to intergenerational change.

\section{Attitudes towards welfare benefits and universal basic income}

Economic self-sufficiency describes the extent to which individuals are able to provide for themselves without external aid. Such aid, in the case of young adults, typically comes in the form of economic support from the family and/or the welfare state (Esping-Andersen 1999). Chevalier (2016) shows that in some European countries, families play a crucial role for the direct or indirect provision of welfare support, indicating that welfare regimes are "familialised" (Esping-Andersen 1999; see also Saraceno 2016). In other countries, such as Sweden, welfare support for young people is "defamilialised", which means that young people are treated no different than adults and they are entitled to the same social rights regardless of age. In Southern European countries such as Italy, families are the units that directly supply welfare support. With this welfare mode, there is also a risk of concentration of wealth in families when the state does not provide welfare support. In Continental European countries such as Germany, while welfare support is provided by the state, practically, it is supplied via the family.

Family support may take a psychological toll on the individuals, by lowering the recipients' self-esteem or undermining their feeling of independence and self-efficacy (Fingerman et al. 2013). Consequently, young adults who are not economically self-sufficient may develop a preference for generous (and "defamilialised") social policies or other forms of wealth redistribution as an alternative to the direct support from the family.

Preferences for redistribution are a heavily researched topic in political economy, as (re-)distributional preferences are in essence the main source of division between the economic left and right in most democracies (Alesina and Giuliano 2011). Many of the explanations proposed elaborate on two broad mechanisms. 


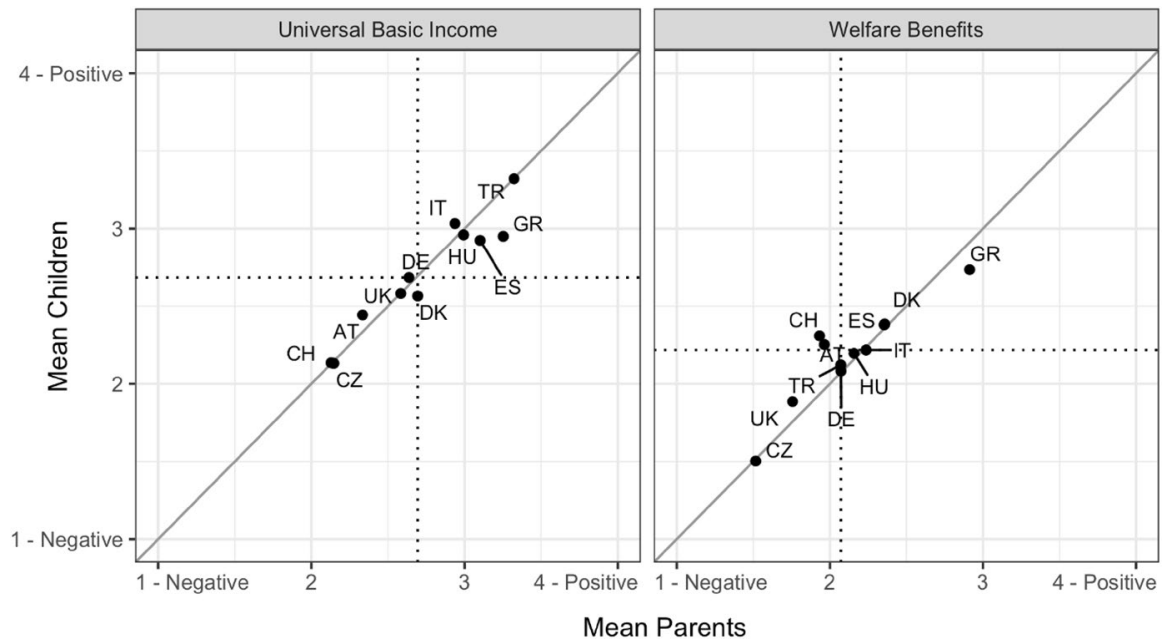

Fig. 3 Attitudes of young people and their parents on universal basic income and welfare benefits

The first mechanism refers to economic self-interest, where individuals belonging to lower income groups are expected to have a greater preference for redistributive policies. The second mechanism is about individual beliefs, where preferences are shaped by attitudes regarding acceptable degrees of societal inequality or poverty. Such attitudes are shaped by the family (Neundorf et al. 2013; Albacete 2014), either through the transmission of values (Abendschön 2013) or the provision of financial support independent from the state (see Alesina and Giuliano 2011). Moreover, economic self-interest and beliefs are interrelated; individuals tend to justify their own status and the reality surrounding them (see Benabou and Tirole 2006). Their social position, in turn, influences perceptions of inequality and poverty in society (see Dawtry et al. 2015).

While it lies beyond the scope of this article to extensively discuss the determinants of attitudes towards welfare policies and redistribution, we seek to demonstrate that the CUPESSE data provide an opportunity to link young respondents' economic self-sufficiency to their preferences for the corresponding policies, while controlling for their parents' preferences. In particular, we look at the attitudes towards universal minimum income and welfare benefits.

The two items are stimulus sentences to which the respondents were asked to state their level of agreement on a four-point scale, ranging from "strongly disagree" to "strongly agree". The respondents' attitudes towards universal minimum income are captured by the statement "Everyone should have the right to a minimum income even if they are not working". Attitudes towards welfare benefits are 


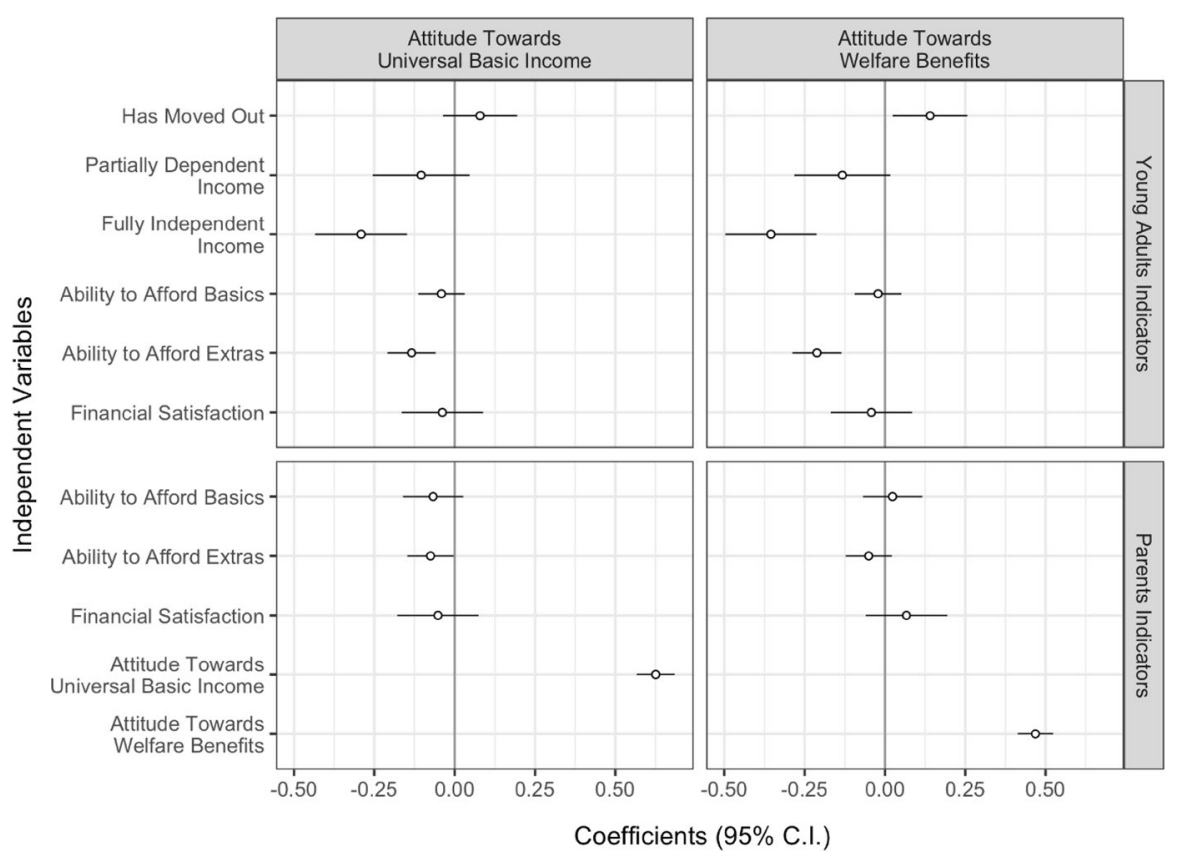

Fig. 4 Results of the ordinal logit regression models

assessed based on the degree of agreement/disagreement with the statement "If welfare benefits are too high there is no incentive to find work". ${ }^{18}$

Figure 3 shows the country averages of the responses given by young adults and their parents. The diagonal lines represent perfect congruence between young adults and parents, while the dotted lines cutting through the plain are the medians. The first striking observation is the similarity between young adults and parents with respect to their attitudes on universal minimum income and welfare benefits. Most observations are on the diagonal lines, or very close to it. Moreover, no clear geographical patterns emerge. While respondents in Southern Europe tend to support a universal minimum income, this pattern does not re-appear with respect to welfare benefits. Overall, Fig. 3 shows that the two generations surveyed in the context of the CUPESSE project are remarkably similar with respect to the two attitudes considered in the 11 countries included in the sample.

How do respondents' preferences for universal minimum income and welfare benefits relate to their own degree of economic self-sufficiency? To answer this question, Fig. 4 shows the coefficients of two ordinal logit models where the two variables are

\footnotetext{
18 The two respective variables are YQ21_f and YQ21_c for the young adults, PMQ18_f and PMQ18_c for the mothers, and PFQ18_f and PFQ18_c for the fathers. The scale of the item on welfare benefits has been reversed for these analyses in order to have both items ranging from a negative to a positive attitude.
} 
regressed on a number of young adults' and parental characteristics. ${ }^{19}$ The two panels at the top show the coefficients of the indicators of young adults' economic self-sufficiency discussed in the previous section. The two panels at the bottom show the coefficients for the parents' ability to afford basic living standards and extras, their financial satisfaction and their responses to the respective attitudinal questions. ${ }^{20}$

Starting with the parents' indicators, the only variables that have a significant and positive effect are the parents' own attitudes on the respective indicators. This is not surprising given the results observed in Fig. 3. In a way, the function of these two variables in the regression models can be regarded as similar to a lagged dependent variable in a time-series regression: they capture all the sources of unobserved individual variation that can be explained, in this case, by family ideology and beliefs. The lack of a significant marginal effect for the three indicators of parental economic situation is also unsurprising, as the contribution of these factors for young adults' preferences is likely to be mediated by the parents' own preferences or by young adults' own economic situation.

Turning to the young adults, a greater ability to afford extras and having a fully independent income are both negatively associated with holding positive attitudes towards both universal basic income and welfare benefits. In other words, the greater the degree of self-sufficiency, the lower the demand for redistributive policies. This finding supports the "rational" explanation of preferences, according to which people who are worse-off economically are more likely to support generous welfare policies. Finally, respondents who do not live with their parents tend, on average, to have a slightly more positive attitude towards welfare benefits. This may be due to the greater need for public support for individuals who cannot rely on the family to assist with housing costs, for example. Overall, the models show that both the parental and the young respondents' own economic self-sufficiency have an impact on their attitudes towards redistributive policies. We believe that these initial findings merit closer attention by future research, which can draw on the CUPESSE data presented in this article.

\section{Conclusion}

The small snapshot of CUPESSE data we presented here illustrates that there exist numerous noteworthy differences in the socio-economic situation of young people and their parents in Europe, in particular the significant differences with regard to economic self-sufficiency across the two generations. This is an important observation since Europe has entered a critical phase of its integration process with the looming Brexit and the increase in right-wing populist parties benefitting from public support (Corduwener 2017). Against this background, pro-EU politicians such as French President Emanuel Macron have called for deepening the EU through

\footnotetext{
19 See Table A1 in the Supplemental Material for the full model results, including country dummies and cut points between the response categories.

20 All variables are coded in the same way as explained previously.
}

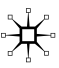


intensified integration. Yet considering the differences in the perceived and actual living conditions of young people in the EU, particularly when compared to their parents' generation, such calls may fail to attract support and even backfire (see Kaina 2013). This finding becomes even more important when considering that young people have typically been the main supporters of European integration in the past. Therefore, we believe that the unfolding debate on reforming the EU must take into account not only geographical differences, but also-and arguably even more so-intergenerational differences and treat these as a starting point for policy action. We are certain that the empirical approach developed by the CUPESSE project can be useful in informing future research and policy-making.

The CUPESSE data not only provide information on economic self-sufficiency for two generations, but also cover a wide range of additional topics that provide a nuanced picture of young Europeans' socio-economic situation. The dataset offers insights into the cultural and social capital endowment of young people as well as their values with regard to work. It also contains information that can help explain how young people make decisions regarding education and training, employment and selfemployment (e.g. Mühlböck et al. 2017; Dvouletý et al. 2018). The dataset has variables relating to the health status of the respondents (Vancea and Utzet 2017, 2018) as well as their experiences using public services when searching for employment (see Shore and Tosun 2017). Rather unusual for a dataset in political science, it also contains information on parenting style (with a view towards better understanding the intergenerational transmission of values and resources; see Warmuth et al. 2015) and concepts related to personality and grit (see Arco-Tirado et al. 2018).

Overall, this data source allows social scientists to investigate the multidimensionality of the challenges young people currently face, and how these challenges impact their attitudes on welfare policies and redistribution.

Acknowledgements We thank Michael Camasso and Radha Jagannathan as well as Asimina Christoforou, Gerbert Kraaykamp, Fay Makantasi, Tiziana Nazio, Kyriakos Pierrakakis, Jacqueline O'Reilly and Jan van Deth for their contribution to the CUPESSE project (Seventh Framework Programme; Grant Agreement No. 61325). CUPESSE received additional funding from the Mannheim Centre for European Social Research (MZES) and the Field of Focus 4 "Self-Regulation and Regulation: Individuals and Organisations" at Heidelberg University. We further acknowledge helpful comments on this article by two anonymous reviewers. Julian Rossello provided valuable research assistance.

Open Access This article is distributed under the terms of the Creative Commons Attribution 4.0 International License (http://creativecommons.org/licenses/by/4.0/), which permits unrestricted use, distribution, and reproduction in any medium, provided you give appropriate credit to the original author(s) and the source, provide a link to the Creative Commons license, and indicate if changes were made.

\section{References}

Abendschön, S. 2013. Children's political socialisation within the family: Value transmission and social milieu factors. In Growing into politics, contexts and timing of political socialisation, ed. S. Abendschön, 33-71. Colchester: ECPR Press.

Abendschön, S., and M. Tausendpfund. 2017. Political knowledge of children and the role of sociostructural factors. American Behavioral Scientist 61(2): 204-221. 
Albacete, G.G. 2014. Young people's political participation in Western Europe: Continuity or generational change?. London: Palgrave Macmillan.

Alford, J.R., C.L. Funk, and J.R. Hibbing. 2005. Are political orientations genetically transmitted? American Political Science Review 99(2): 153-167.

Andriopoulou, E., A. Karakitsios, and P. Tsakloglou. 2018. Inequality and poverty in Greece: Changes in times of crisis. In Socioeconomic fragmentation and exclusion in Greece under the crisis, ed. D. Katsikas, D.A. Sotiropoulos, and M. Zafiropoulou, 23-54. London: Palgrave Macmillan.

Alesina, A., and P. Giuliano. 2011. Preferences for redistribution. In Handbook of social economics, ed. J. Benhabib, A. Bisin, and M. Jackson, 93-131. San Diego: North-Holland.

Arco-Tirado, J.L., F.D. Fernandez-Martin, and R. Hoyle. 2018. Development and validation of a Spanish version of the Grit-S scale. Frontiers in Psychology 9(96): 1-7.

Arnett, J.J. 2014. Emerging adulthood: The winding road from the late teens through the twenties. New York: Oxford University Press.

Baranowska-Rataj, A., S. Bertolini, C. Ghislieri, A. Meo, V. Moiso, R. Musumeci, and P.M. Torrioni. 2016. Becoming adult in hard times: Current and future issues on job insecurity and autonomy. Turin: Accademia University Press.

Benabou, R., and J. Tirole. 2006. Belief in a just world and redistributive politics. The Quarterly Journal of Economics 121(2): 699-746.

Bonoli, G., and D. Natali. 2012. The politics of the new welfare state. Oxford: Oxford University Press.

Bourdieu, P. 1997. The forms of capital. In Education, culture, economy, society, ed. A.H. Halsey, H. Lauder, P. Brown, and A.S. Wells, 46-58. New York: Oxford University Press.

Busemeyer, M.R., and C. Jensen. 2012. The impact of economic coordination and educational institutions on individual-level preferences for academic and vocational education. Socio-Economic Review 10(3): 525-547.

Campanella, F., M.R. Della Peruta, and M. Del Giudice. 2013. The role of sociocultural background on the characteristics and the financing of youth entrepreneurship. An exploratory study of university graduates in Italy. Journal of the Knowledge Economy 4(3): 244-259.

Cemalcilar, Z., and F. Gökşen. 2014. Inequality in social capital: Social capital, social risk and drop-out in the Turkish education system. British Journal of Sociology of Education 35(1): 94-114.

Chevalier, T. 2016. Varieties of youth welfare citizenship: Towards a two-dimension typology. Journal of European Social Policy 26(1): 3-19.

Christoforou, A. 2011. Social capital across European countries: Individual and aggregate determinants of group membership. American Journal of Economics and Sociology 70(3): 699-728.

Corduwener, P. 2017. Integrating contemporary populism with the history of democracy in Western Europe. European Political Science 16(2): 206-216.

Davidsson, P., and B. Honig. 2003. The role of social and human capital among nascent entrepreneurs. Journal of Business Venturing 18(3): 301-331.

Dawtry, R.J., R.M. Sutton, and C.G. Sibley. 2015. Why wealthier people think people are wealthier, and why it matters: From social sampling to attitudes to redistribution. Psychological Science 26(9): 1389-1400.

Debus, M., M. Stegmaier, and J. Tosun. 2014. Economic voting under coalition governments: Evidence from Germany. Political Science Research and Methods 2(1): 49-67.

Dion, M.L., and V. Birchfield. 2010. Economic development, income inequality, and preferences for redistribution. International Studies Quarterly 54(2): 315-334.

Dvouletý, O., M. Mühlböck, J.R. Warmuth, and B. Kittel. 2018. 'Scarred' young entrepreneurs. Exploring young adults' transition from former unemployment to self-employment. Journal of Youth Studies. https://doi.org/10.1080/13676261.2018.1450971.

Emmenegger, P., P. Marx, and D. Schraff. 2017. Off to a bad start: Unemployment and political interest during early adulthood. Journal of Politics 79(1): 315-328.

Esping-Andersen, G. 1999. Social foundations of postindustrial economies. Oxford: Oxford University Press.

Eurostat. 2017. Comparative price levels of consumer goods and services. http://ec.europa.eu/euros tat/statistics-explained/index.php/Comparative_price_levels_of_consumer_goods_and_services. Accessed 7 Mar 2018.

Fazekas, Z., and L. Littvay. 2015. The importance of context in the genetic transmission of U.S. party identification. Political Psychology 36(4): 361-377.

Fingerman, K.L., Y.P. Cheng, K.E. Cichy, K.S. Birditt, and S. Zarit. 2013. Help with "strings attached": Offspring perceptions that middle-aged parents offer conflicted support. Journals of Gerontology. Series B, Psychological Sciences and Social Sciences 68(6): 902-911. 
Freitag, M., and A. Kirchner. 2011. Social capital and unemployment: A macro-quantitative analysis of the European regions. Political Studies 59(2): 389-410.

Gowdy, E.A., and S. Pearlmutter. 1993. Economic self-sufficiency: It's not just money. Affilia 8(4): 368-387.

Hetling, A., G.L. Hoge, and J.L. Postmus. 2016. What is economic self-sufficiency?: Validating a measurement scale for policy, practice, and research. Journal of Poverty 20(2): 214-235.

Hobolt, S.B. 2016. The Brexit vote: A divided nation, a divided continent. Journal of European Public Policy 23(9): 1259-1277.

Isengard, B., R. König, and M. Szydlik. 2017. Money or space? Intergenerational transfers in a comparative perspective. Housing Studies 33(2): 1-23.

Jagannathan, R., M.J. Camasso, B. Das, J. Tosun, and S. Iyengar. 2017. Family, society and the individual: Determinants of entrepreneurial attitudes among youth in Chennai, South India. Journal of Global Entrepreneurship Research 7(14): 1-22.

Jensen, C. 2008. Worlds of welfare services and transfers. Journal of European Social Policy 18(2): $151-162$.

Jensen, C., C. Arndt, S. Lee, and G. Wenzelburger. 2018. Policy instruments and welfare state reform. Journal of European Social Policy 28(2): 161-176.

Jost, J.T. 2006. The end of the end of ideology. American Psychologist 61(7): 651-670.

Kaina, V. 2013. How to reduce disorder in European identity research. European Political Science 12(2): 184-196.

Kraaykamp, G., and P. Nieuwbeerta. 2000. Parental background and lifestyle differentiation in Eastern Europe: Social, political, and cultural intergenerational transmission in five former socialist societies. Social Science Research 29(1): 92-122.

Kraaykamp, G., and K. Van Eijck. 2010. The intergenerational reproduction of cultural capital: A threefold perspective. Social Forces 89(1): 209-231.

Ladi, S. 2014. Austerity politics and administrative reform: The Eurozone crisis and its impact upon Greek public administration. Comparative European Politics 12(2): 184-208.

Lahusen, C., N. Schulz, and P.R. Graziano. 2013. Promoting social Europe? The development of European youth unemployment policies. International Journal of Social Welfare 22(3): 300-309.

Leibson, R.H. 2005. From self-sufficiency to personal and family sustainability: A new paradigm for social policy. Journal of Sociology and Social Welfare 32(4): 77-92.

Lorenzini, J., and M. Giugni. 2012. Employment status, social capital, and political participation: A comparison of unemployed and employed youth in Geneva. Swiss Political Science Review 18(3): 332-351.

Maloney, W. A., and S. Roßteutscher (eds.). 2009. Social capital and associations in European democracies: A comparative analysis. London: Routledge.

Maloney, W. A., and J. van Deth (eds.). 2010. Civil society and activism in Europe: Contextualizing engagement and political orientations. London: Routledge.

Melo, D.F., and D. Stockemer. 2014. Age and political participation in Germany, France and the UK: A comparative analysis. Comparative European Politics 12(1): 33-53.

Mühlböck, M., J.R. Warmuth, M. Holienka, and B. Kittel. 2017. Desperate entrepreneurs: No opportunities, no skills. International Entrepreneurship and Management Journal. https://doi. org/10.1007/s11365-017-0472-5.

Neundorf, A., K. Smets, and G.M. García-Albacete. 2013. Homemade citizens: The development of political interest during adolescence and young adulthood. Acta Politica 48(1): 92-116.

OECD. 2007. Society at a glance: OECD social indicators. 2006th ed. Paris: OECD.

O’Reilly, J., W. Eichhorst, A. Gábos, K. Hadjivassiliou, D. Lain, J. Leschke, S. McGuinness, L.M. Kureková, T. Nazio, R. Ortlieb, and H. Russell. 2015. Five characteristics of youth unemployment in Europe. Sage Open 5(1): 1-19.

Quintelier, E. 2013. Engaging adolescents in politics. Youth and Society 47(1): 51-69.

Rapp, C., J. Shore, and J. Tosun. 2018. Not so risky business? How social policies shape the perceived feasibility of self-employment. Journal of European Social Policy 28(2): 143-160.

Roßteutscher, S. 2010. Social capital worldwide: Potential for democratization or stabilizer of authoritarian rule? American Behavioral Scientist 53(5): 737-757.

Saraceno, C. 2016. Varieties of familialism: Comparing four southern European and East Asian welfare regimes. Journal of European Social Policy 26(4): 314-326.

Schönpflug, U. 2009. Epilogue: Toward a model of cultural transmission. In cultural transmission, ed. U. Schönpflug, 460-478. New York: Cambridge University Press. 
Shore, J., and J. Tosun. 2017. Assessing youth labour market services: Young people's perceptions and evaluations of service delivery in Germany. Public Policy and Administration. https://doi.org/10.1177/09520 76717722192.

Shore, J., and J. Tosun. 2018. A two-generation study in Germany: Insights into survey data collection. SAGE Research Methods Cases: Politics and International Relations. forthcoming.

Steiber, N. 2016. First findings from employer interviews, country report: Austria. CUPESSE working paper 4. http://cupesse.eu/fileadmin/cupesse/downloads/working-papers/CUPESSE_Working-Paper_4.pdf. Accessed 25 June 2018.

Svallfors, S. (ed.). 2012. Contested welfare states: Welfare attitudes in Europe and beyond. Stanford: Stanford University Press.

Tosun, J. 2017. Promoting youth employment through multi-organizational governance. Public Money and Management 37(1): 39-46.

Tosun, J., S. Speckesser, C. Jensen, and J. O'Reilly. 2016. The absorption of structural and investment funds and youth unemployment. In EU cohesion policy: Reassessing performance and direction, ed. J. Bachtler, P. Berkowitz, S. Hardy, and T. Muravska, 151-168. London: Routledge.

Tosun, J., M. Unt, and E. Wadensjö. 2017. Youth-oriented active labour market policies: Explaining policy effort in the nordic and the Baltic States. Social Policy and Administration 51(4): 598-616.

Tosun, J., A. Wetzel, and G. Zapryanova. 2014. The EU in crisis: Advancing the debate. Journal of European Integration 36(3): 195-211.

Tosun, Jale, Felix Hörisch, Bettina Schuck, Jennifer Shore, Michael Woywode, Robert Strohmeyer, Bernhard Kittel, et al. 2018. CUPESSE: Cultural pathways to economic self-sufficiency and entrepreneurship. Cologne: GESIS. https://doi.org/10.4232/1.13042.

Trommsdorff, G. 2009. Intergenerational relations and cultural transmission. In Cultural transmission, ed. U. Schönpflug, 126-160. New York: Cambridge University Press.

Vancea, M., and M. Utzet. 2017. How unemployment and precarious employment affect the health of young people: A scoping study on social determinants. Scandinavian Journal of Public Health 45(1): 73-84.

Vancea, M., and M. Utzet. 2018. School-to-work transition: The case of Spanish NEETs. Journal of Youth Studies 21: 869-887.

Van Deth, J.W., S. Abendschön, and M. Vollmar. 2011. Children and politics: An empirical reassessment of early political socialization. Political Psychology 32(1): 147-174.

Vegetti, F., and D. Adăscăliţei. 2017. The impact of the economic crisis on latent and early entrepreneurship in Europe. International Entrepreneurship and Management Journal 13(4): 1289-1314.

Warmuth, J.R., B. Kittel, N. Steiber, and M. Mühlböck. 2015. Cultural pathways to economic self-sufficiency and entrepreneurship. An overview of theoretical perspectives on micromechanisms. CUPESSE working paper 1. https://cupesse.eu/fileadmin/cupesse/downloads/working-papers/CUPESSE_WorkingPaper_1.pdf. Accessed 25 June 2018.

Weiß, J., and B. Schuck. 2016. First findings from employer interviews, country report: Germany. CUPESSE working paper 5. http://cupesse.eu/fileadmin/cupesse/downloads/working-papers/CUPESSE_WorkingPaper_5.pdf. Accessed 25 June 2018.

Jale Tosun is professor at the Institute of Political Science at Heidelberg University. Her research focuses on comparative public policy, international political economy and public administration.

Jose L. Arco-Tirado is professor at the Faculty of Education at the University of Granada. His research focuses on psychological and educational factors determining competencies and employability.

Maurizio Caserta is professor of economics at the University of Catania, Department of Economics and Management. His research focuses on the economic analysis of institutions, local development and migration economics.

Zeynep Cemalcilar is an associate professor of social psychology at Koç University, Turkey. Her current research focuses on positive youth development, motivation, psychological interventions and the use of technology in the social life.

Markus Freitag is professor at the Institute of Political Science at the University of Bern. His research focuses on political sociology. 
Felix Hörisch is Lecturer and Postdoctoral Researcher Heidelberg University. His research interests include comparative policy analysis, political economy, labour markets, social and fiscal policies.

Carsten Jensen is professor in the Department of Political Science at Aarhus University. His research is focused on the causes and consequences of redistributive politics in advanced western democracies, as well as democratic representation more broadly.

Bernhard Kittel is professor of economic sociology at the University of Vienna. His current research focuses on justice attitudes, collective decision-making and youth labour market participation.

Levente Littvay is associate professor of Political Science at Central European University in Budapest, Hungary. He researches quantitative methods, psychology of populism and genetics/socialisation in twin and family studies.

Martin Lukeš is head of the entrepreneurship department at the University of Economics, Prague. His research focuses on psychology of entrepreneurship, evaluation of entrepreneurship policies and self-employment.

William A. Maloney is the Head of the School of Geography, Politics and Sociology at Newcastle University where he is Professor of Politics. His research interests include: interest groups, civil society organisations and political participation.

Monika Mühlböck is a post doc at the Department of Economic Sociology at the University of Vienna. She mainly studies labour market policies and European integration.

Emily Rainsford is a research associate at Newcastle University. Her research focuses on the political activism of young people in the UK and Europe.

Carolin Rapp is an assistant professor at the Department of Political Science at the University of Copenhagen. Her research is situated in the areas of political sociology, political psychology and social policy.

Bettina Schuck is a postdoctoral researcher at the Institute of Political Science at Heidelberg University. Her research focuses on social inequality and stratification in a country-comparative perspective.

Jennifer Shore is a postdoctoral fellow at the Mannheim Centre for European Social Research at the University of Mannheim. Her research interests include political behaviours and attitudes, welfare states and comparative public policy.

Nadia Steiber is senior researcher at the Institute for Advanced Studies, Vienna, Austria. Her research interests comprise the sociology of work, youth unemployment, women's work and employment, migrant labour markets and challenges of ageing societies.

Nebi Sümer is professor of psychology at Middle East Technical University, Turkey. His research interests are parenting, attachment across the lifespan, road user behaviours and the effects of unemployment.

Panos Tsakloglou is professor at the Department of International and European Economic Studies of the Athens University of Economics and Business. His research focuses on inequality, poverty, social exclusion and the redistributive role of the welfare state.

Mihaela Vancea is a social science researcher at Pompeu Fabra University, Barcelona, Spain. Her main research areas are employability and entrepreneurship of young people as well as health and well-being.

Federico Vegetti is a post doc research fellow at the University of Milan in Italy. His research interests lie at the intersection between political science, sociology and psychology, which he investigates using mostly quantitative methods. 